DOI https://doi.org/10.30525/978-9934-26-007-0-20

\title{
ПЕРЕДАЧА ПЕРСОНАЛЬНИХ ДАНИХ ЯК СПОСІБ ВІДПЛАТНОСТІ У ДОГОВОРАХ ПОСТАЧАННЯ ЦИФРОВОГО КОНТЕНТУ
}

\section{Стахира Г. М., Баран А. В.}

\section{ВСТУП}

Стрімкий науково-технічний прогрес, впровадження у щоденне життя користувачів комп'ютерних та інформаційних технологій призвели до збільшення обсягів і напрямів використання інформації, в т. ч. збору, обробки та зберігання даних про особу, яка є суб'єктом приватноправових відносин. Широке використання автоматизованих інформаційних систем сприяє виникненню відкритого банку інформації про особу, накопичення i використання якої може привести до порушення іiі законних інтересів, виникнення матеріальної або моральної шкоди.

Впровадження в економічні відносини новітніх технологій сприяло виникненню нових технічних способів укладення договорів, за якими здійснюється постачання цифрового контенту. Одержувачі можуть обрати засіб здійснення такого постачання серед його численних підвидів. Так, популярними є: постачання цифрового контенту «на вимогу», тобто за персональним запитом одержувача, його завантаження шляхом натиснення спеціальної кнопки на веб-сторінці постачальника, отримання цифрового контенту через потокову та веб-трансляцію онлайн, шляхом під’єднання IP-адреси до телевізійного каналу передачі даних, підписки на придбання електронних книг, електронних журналів та електронних газет, завантаження мобільних додатків, здійснення онлайн-покупок у додатках, використання хмарних технологій та багато іншого. Таким ж різноманітним $\epsilon$ і спосіб здійснення оплати за надання цифрових даних, що варіюється від передання грошових коштів до виконання зобов'язань у натурі (зокрема отримання на електронну пошту та перегляд онлайн рекламних матеріалів, підбір контекстної реклами, проходження анкетування для розробки маркетингової стратегії постачальника та ін.). Водночас технологічний прогрес уможливлює використання персональних даних як нової форми відплатності у зобов'язаннях з метою набуття товарів і послуг у цифровій формі. Наведене зумовлює необхідність розробки ефективного регулювання використання персональних даних, у т. ч. у договорах, за якими здійснюється обіг цифрового контенту. 


\section{1. Передання персональних даних онлайн: «click wrap» $\mathrm{i}$ «browse wrap» договори}

Передання персональних даних як форма відплатності за договором постачання цифрового контенту $є$ відносно новим рішенням у законодавстві Європейського Союзу (далі - ЄС). Вперше такий обов'язок одержувача контенту закріплено у проекті Директиви 2015/0287 про договори постачання цифрового контенту. Ч. 1 ст. 3 визначає, що на виконання договору постачання цифрового контенту його одержувач зобов'язується сплатити визначену ціну або вчинити іншу зустрічну дію у формі надання персональних або інших даних ${ }^{1}$. Пізніше прийнята Директива 2019/770 про договори постачання цифрового контенту та цифрових послуг містить подібну конструкцію зобов'язання одержувача цифрового контенту сплатити на користь постачальника визначену ціну або надати власні персональні дані, за винятком необхідності їх передання виключно для здійснення постачання цифрового контенту, без мети використання постачальником у жодних інших ціля ${ }^{2}$. Формулювання обов'язку одержувача цифрового контенту у формі сплати визначеної ціни не обмежується переданням грошових коштів. Погоджуємося з А. Клейном, що відплатність у договірних зобов'язаннях характеризується обміном між сторонами об'єктами, які мають визначену майнову вартість ${ }^{3}$. Про майнову вартість об'єкта свідчить бажання суб'єктів договірних відносин його отримати за плату, що встановлює таким чином ринкову вартість для певного товару чи послуги ${ }^{4}$.

Постачання цифрового контенту відбувається на підставі договорів приєднання, що зазвичай укладаються онлайн. К. Пормейстер зазначає, що передача, накопичення та використання персональних даних відбувається шляхом укладення договорів постачання цифрового контенту за посередництвом автоматизованих систем онлайн. У зазначених випадках досягнення згоди сторін 3 усіх істотних умов окремого договору не відбувається, а договір укладається на підставі автоматизованої обробки поданої сторонами інформації. Прикладом таких автоматично укладених

\footnotetext{
${ }^{1}$ Proposal for a Directive of the European Parliament and of the Council on certain aspects concerning contracts for the supply of digital content COM/2015/0634 final - 2015/0287 (COD). URL: https://eur-lex.europa.eu/ legal-content/EN/TXT/?uri=celex\%3A52015PC0634.

${ }^{2}$ Directive (EU) 2019/770 of the European Parliament and theof the Councilof 20 May 2019 on certain aspects concerning contracts for the supply of digital content and digital services. URL: https://eur-lex.europa.eu/legalcontent/EN/TXT/PDF/?uri=CELEX:32019L0770\&from=EN.

3 Klein A. Elementy zobowiązaniowego stosunku prawnego. Wrocław : Wydawnictwo Uniwersytetu Wrocławskiego. 2005. $200 \mathrm{~s}$.

${ }^{4}$ Nowacka I. Umowa o dostarczeniu tresci cyfrowych. Kraków, 2017. $420 \mathrm{~s}$.

${ }^{5}$ Pormeister K. Informed consent to sensitive personal data processing for the performance of digital consumer contracts on the example of '23andMe'. Journal of European Consumer and Market Law. 2017. № 1. P. 17-24.
} 
договорів можуть слугувати сервіси, які постачають цифровий контент на підставі реєстрації користувачів. Одержувач цифрового контенту заповнює на веб-сторінці постачальника спеціальну форму, де зазвичай вказуються персональні дані, в т. ч. адреса електронної пошти, і завершення реєстрації та отримання цифрового контенту $є$ неможливим без надання згоди на обробку та використання персональних даних, погодження 3 умовами договору без можливості внесення у нього будь-яких змін чи застережень.

У літературі виділяють два основні види договорів постачання цифрового контенту, укладених онлайн, відплатний характер яких реалізовується шляхом надання одержувачем згоди на обробку та використання власних персональних даних постачальником. Першим iз зазначених видів $\epsilon$ договори, що укладаються у спосіб «click wrap», а погодження умов здійснюється шляхом заповнення чекбоксу (checkbox), відображеного на екрані у вигляді квадрата невеликого розміру, який може мати два стани: $\square$ «вимкнено» (пусто) та $\square$ «ввімкнено ${ }^{6}$. Ввімкнений чекбокс активує кнопку кінцевого автоматичного укладення договору, що зазвичай має назву «готово» та відкриває доступ користувачу до цифрового контенту. Другим видом є договори, укладені у спосіб «browse wrap», надання згоди на обробку i використання персональних даних шляхом завантаження одержувачем веб-сторінки постачальника, наприклад, перегляд електронного журналу онлайн автоматично дозволяє використовувати кукі (cookie) файли користувача.

Варто відзначити, що у разі укладення договору шляхом використання технології «click wrap» його умови відображаються на завантаженій вебсторінці, а одержувач цифрового контенту їх погоджує шляхом заповнення чекбоксу, натиснення кнопки «я погоджуюся» або будь-якою іншою активною дією на сторінці. Залежно від типу програмування, що використовується для постачання цифрового контенту онлайн, така необхідність вираження явної згоди одержувача з умовами договору може виникати на одному або кількох етапах його укладення: при завантажені цифрового контенту, при встановленні програмного забезпечення, яке уможливлює роботу цифрового контенту ${ }^{7}$.

Проте найчастіше уживаним залишається використання моделі укладення договору «browse wrap», коли його умови відображаються на вебсторінці постачальника, а одержувачу цифрового контенту надається для

\footnotetext{
${ }^{6}$ Прапорець (елемент $\quad$ GUI). URL: https://uk.wikipedia.org/wiki/\%D0\%9F\%D1\%80\%D0\%B0\%D0\% BF\%D0\%BE\%D1\%80\%D0\%B5\%D1\%86\%D1\%8C_(\%D0\%B5\%D0\%BB\%D0\%B5\%D0\%BC\%D0\%B5\%D0\% BD\%D1\%82_GUI).

${ }^{7}$ Helberger N., Loos M., Guibault L., Mak C., Pessers L. Digital content contracts for consumers. Journal of Consumer Policy. 2013. Vol. 36. Issue 1. P. 37-57.
} 
ознайомлення доступ до них за відповідним посиланням ${ }^{8}$. Щоб договір постачання цифрового контенту вважався укладеним, його одержувачу не потрібно натискати будь-яких посилань чи спеціальних кнопок, заповнювати чекбокс, адже відвідання веб-сторінки розглядається як автоматична згода на укладення договору (про існування якого користувач може навіть і не здогадуватись), за умовами якого надається дозвіл на використання персональних даних 9 .

\section{2. Монетизація персональних даних: практика ЄС і перспективи впровадження у національне законодавство}

Договір постачання цифрового контенту залежно від його умов може бути як відплатним (у разі сплати одержувачем цифрового контенту певної грошової суми), так і безвідплатним.

Дефініція досліджуваного договору у проекті Директиви 2015/0287 про договори постачання цифрового контенту й у прийнятій Директиві 2019/770 про договори постачання цифрового контенту та цифрових послуг визначає можливість одержувачем цифрового контенту виконати зустрічне зобов'язання за договором у формі: а) сплати визначеної грошової суми; б) надання постачальнику персональних даних; в) надання постачальнику інших даних. Надання даних, які використовуються постачальником виключно для реалізації мети договору та не накопичуються для будь-яких інших комерційних цілей, не впливає на визначення відплатності договору.

Аналізуючи норми вітчизняного законодавства, відзначимо, що презумпція відплатності договору закріплена у ч. 5 ст. 626 ЦК України. Конструкція наведеної норми покликана насамперед забезпечити захист законних інтересів сторін договору за відсутності в його умовах положень про ціну. Відповідно до ч. 4 ст. 632 ЦК України, якщо в умовах договору не встановлена ціна, вона визначається, виходячи зі звичайних цін, що склалися на аналогічні товари, роботи або послуги на момент укладення договору. Виходячи 3 наведених норм, необхідною умовою для визначення договору безвідплатним $є$ наявність у його положеннях прямої вказівки на це.

Враховуючи нематеріальну правову природу цифрового контенту, його постачання здійснюється на матеріальних носіях або у формі потокової передачі даних онлайн. У разі укладення договору, предметом якого $є$ цифровий контент, розміщений на зовнішньому накопичувальному пристрої

\footnotetext{
${ }^{8}$ Helberger N., Loos M., Guibault L., Mak C., Pessers L. Digital content contracts for consumers. Journal of Consumer Policy. 2013. Vol. 36. Issue 1. P. 37-57.

${ }^{9}$ Pormeister K. Informed consent to sensitive personal data processing for the performance of digital consumer contracts on the example of '23andMe'. Journal of European Consumer and Market Law. 2017. № 1. P. 17-24.
} 
(CD; DVD), що має матеріальну форму вираження, його передання зазвичай супроводжується оплатою визначеної грошової суми. Проте у разі постачання цифрового контенту онлайн на одноразовій (перегляд фільму онлайн) чи постійній основі (зберігання даних у хмарному сховищі) одержувач цифрового контенту зазвичай надає свої персональні або інші дані шляхом реєстрації чи використання файлів кукі, заповнюючи анкети, переглядаючи рекламні ролики, підписуючись на інтернет-сторінки та ін., що використовуються постачальником для розробки маркетингової стратегії, методів надання рекламної інформації та ін.

Європейський законодавець прирівнює надання персональних або інших даних постачальнику цифрового контенту до виконання грошового зобов'язання за договором. Зазначене дозволяє висловити позицію про монетизацію даних і зумовлює необхідність запровадження до вітчизняного законодавства положень про захист персональних даних.

Вважаємо за доцільне приділити увагу дослідженню «інших даних», що передаються як відплатність за договорами постачання цифрового контенту. Ними відповідно до положень Директиви Європейського Парламенту i Ради 2002/58/ЄС про обробку персональних даних та захист приватності в галузі електронної комерції від 12 липня $2002 \mathrm{p}^{10} \epsilon$ :

- конфіденційні дані, які містять у собі зміст повідомлень, надісланих під час електронних листувань;

- дані, необхідні для встановлення та підтримання зв'язку: інформація про трафік, провайдерів, час з'єднання та його загальну тривалість;

- дані про місцезнаходження електронних пристроїв, із яких користувачі здійснювали під'єднання до мережі Інтернет у конкретний момент. Зазначена інформація стосується також відстежування місця знаходження особи через технологію системи глобального позиціонування (Global Positioning System), що застосовується сучасними мобільними пристроями.

Використання постачальником інформації про трафік допускається виключно $з$ метою визначення його загальної кількості та виставлення одержувачу рахунку на оплату. Як зазначається у Довіднику з Європейського права у галузі захисту персональних даних, підготованому спільно Радою $С$ та Агентством основних прав $\mathrm{CC}$, вищезгадані дані за згодою особи можуть бути передані для обробки іншими постачальниками, котрі пропонують надання цифрового контенту та цифрових послуг за додаткову оплату. До них належить: обробка даних про

\footnotetext{
${ }^{10}$ Directive of the European Parliament and the Council concerning the processing of personal data and the protection of privacy in the electronic communications sector (Directive on privacy and electronic communications) 2002/58/EC dated 12.07.2002. URL: http://eur-lex.europa.eu/legal-content/EN/TXT/?uri= celex\%3A32002L0058.
} 
місцезнаходження особи $з$ метою надання ій інформації про найближчі маршрути до визначеного місця (аптеки, ресторану, зупинки громадського транспорту), прогнозу погоди у місцевості, де особа знаходиться та ін. ${ }^{11}$

На практиці одержувачі цифрового контенту доволі часто натрапляють на труднощі із доступом до нього. Так, веб-сторінки, що, на перший погляд, спрямовані на безвідплатне постачання цифрового контенту, використовують програмне забезпечення, яке унеможливлює завантаження даних без заповнення «спливаючого» вікна (Рop-up ad) у формі натискання кнопки «я погоджуюся» або заповнення відповідного чекбоксу. Отримання цифрового контенту у таких випадках $є$ наслідком вираження згоди на обробку та використання постачальником персональних і будь-яких інших даних.

Описаний вище механізм постачання даних створює в одержувача враження укладеного договору на безвідплатній основі, проте це не так, адже постачальники цифрового контенту та цифрових послуг у формі соціальних медіаресурсів, пошукових систем, додатків, що створюються для забезпечення зв'язку між їхніми користувачами шляхом листування, аудіо та відео з'єднання онлайн, хостинг-платформи для зберігання даних та ін., за своєю суттю є великими рекламними майданчиками, котрі обробляють персональні дані користувачів із метою підбору контекстної реклами залежно від відвідуваних раніше сторінок, пошукових запитів, віку, роду занять, розміщення тощо. Наведене є електронним ринком продажу персональних даних користувачів i розміщення рекламної продукції, що працює під виглядом безвідплатного постачання цифрового контенту ${ }^{12}$.

Поширення описаної моделі використання персональних даних онлайн сприяло новелізації законодавства ЄС у цій сфері. Так, у 2009 р. було внесено зміни до Директиви Свропейського Парламенту і Ради 2002/58/СС про обробку персональних даних і захист приватності в галузі електронної комерції, що передусім включали:

- застосування обмежень щодо надсилання особам електронних листів і коротких повідомлень рекламного змісту у мобільних додатках із метою виконання маркетингової стратегії, реклами товарів і послуг. Подібні листи можуть відправлятися у разі вираження явної згоди одержувача на це. Крім того, законодавець дозволяє адресувати рекламні повідомлення попереднім одержувачам, зареєстрованим у сервісі постачальника цифрового контенту, якщо вони, при реєстрації, надали дозвіл на їх отримання;

\footnotetext{
${ }^{11}$ Handbook on European data protection law. URL: http://www.echr.coe.int/Documents/Handbook_data_ protection_ENG.pdf.

${ }^{12}$ Metzger A. Data as Counter-Performance: What Rights and Duties do Parties Have? URL: https://www.jipitec.eu/issues/jipitec-8-1-2017/4528.
} 
- держави-члени ЄС зобов'язані забезпечити ефективний судовий захист порушених прав користувачів, яким надсилаються рекламні повідомлення без надання на це явної згоди;

- налаштування кукі-файлів, що відстежують дії користувача сервісу та зберігають інформацію про них, у спосіб, що уможливлює такий збір та обробку, лише за умови вираження явної згоди користувача.

Наведені зміни до законодавства про використання персональних даних онлайн підтверджують підтримку законодавцем $\mathrm{CC}$ положення про економічну вартість персональних даних. Ще одним аргументом позиції про монетизацію персональних даних $\epsilon$ підтверджений факт використання персональних та інших даних як предмету договорів, які укладаються між постачальниками цифрового контенту та рекламодавцями ${ }^{13}$. Деякі дослідники, серед яких Р. Манко та Н. Пуртова, висловлюють твердження про необхідність застосування юридичної фікції та поширення на персональні дані правового режиму майна, тобто фактичного прирівняння права власності на майно (jus ad rem) і права власності на персональні дані ${ }^{14}$.

Обгрунтовуючи доцільність включення положень про монетизацію даних у законодавство $Є C$, Р. Манко наголошує на необхідності регулювання наявних на світовому цифровому ринку бізнес-моделей, відповідно до яких надання даних $\epsilon$ одним із найпопулярніших способів відплатності у договірних зобов'язаннях ${ }^{15}$.

Варто наголосити, що у преамбулі Директиви 2019/770 про договори постачання цифрового контенту та цифрових послуг закріплено положення про поширення норм директиви на правовідносини, у яких суб'єкту підприємницької діяльності надаються персональні дані особи й уможливлюється їх використання з метою підбору рекламних матеріалів. I хоча, реєструючись у соціальній мережі, користувач заповнює анкету особистої інформації, вказуючи ім'я, адресу, електронну адресу для висвітлення іiі у сервісі, періодично розміщує пости, разом із аудіо-, відео-, фото- та текстовими файлами, надаючи згоду на публікацію інформації онлайн, постачальник послуг все ж таки позбавлений права використовувати вказану інформацію у маркетингових і рекламних цілях без окремої згоди користувача.

Стосовно законодавства України у сфері надання, обробки та захисту персональних даних, то воно перебуває на етапі становлення. Значну цінність цьому процесу надає консолідація законодавства. Так, відповідно до положень ст. 200 ЦК України інформацією є будь-які відомості та / або

\footnotetext{
13 Purtova N. Property rights in personal data: A European perspective. URL: https://pure.uvt.nl/ws/files/ 1312691/Purtova_property16-02-2011.pdf.

${ }^{14}$ Mańko R. Contracts for supply of digital content. A legal analysis of the Commission's proposal for a new directive. URL: http://www.europarl.europa.eu/RegData/etudes/IDAN/2016/582048/EPRS_IDA(2016)582048_EN.pdf.

15 Там само.
} 
дані, які можуть бути збережені на матеріальних носіях або відображені в електронному вигляді, а порядок використання інформації та захисту права на неї встановлюється Законом України «Про інформацію» № 2657-XII. Цей нормативно-правовий акт визначає інформацію про фізичну особу (персональні дані) як відомості чи сукупність відомостей про фізичну особу, котра ідентифікована або може бути конкретно ідентифікована. Аналогічну дефініцію знаходимо й у спеціальному законодавстві, спрямованому на захист персональних даних особи - Законі України «Про захист персо нальних даних» № 2297-VI від 01 червня 2010 р.

Окрім того, вважаємо за необхідне відзначити, що вітчизняне законодавство не встановлює єдиного переліку даних, які належать до персональних. Зокрема, Закон України «Про інформацію» до персональних даних відносить дані про національність фізичної особи, освіту, сімейний стан, релігійні переконання, стан здоров'я, а також іï адресу, дату і місце народження, тоді як галузеве законодавство, наприклад, Закон України «Про адвокатуру та адвокатську діяльність» від 05 липня 2012 р. № 5076-VI, до персональних даних особи відносить перелік питань, із якими особа звертається до адвоката по консультацію, ії зміст, перелік даних, отриманих адвокатом під час здійснення ним своїх професійних обов'язків. Варто відзначити, що європейське законодавство містить відкритий широкий перелік даних, які можуть кваліфікуватися як персональні та, як наслідок, бути предметом обігу. У зв'язку з наведеним цікавим видається рішення Суду Справедливості ЄС від 19 жлвтня 2016 р. у справі № C- 582/18 Patrick Breyer / Bundesrepublik Deutschland ${ }^{16}$, у якому Суд визнає IP-адресу, за якою здійснює продаж товарів зареєстрований онлайн-магазин, інформацією, що входить до переліку персональних даних такого суб'єкта. Вищий Адміністративний суд Республіки Польща в рішенні від 19 травня 2011 р. у справі I OSK 1079/1017 висловив позицію про визнання персональними даними особи як інформації, що безпосередньо іiі ідентифікує (імені, адреси, національності), так і інформації про предмети або технічні пристрої, за умови можливості їх прив'язки до конкретної особи (інформації про $I P$-адресу, місцезнаходження мобільного пристрою у конкретний момент та ін.). IP-адреса технічного пристрою повинна визначатися різновидом персональних даних, що уможливлює ідентифікацію фізичної особи, коли дана IP адреса надана на тривалий період часу певному технічному пристрою, який належить і постійно використовується конкретним користувачем.

\footnotetext{
${ }^{16}$ Wyrok Trybunału w sprawie C-582/14 Patrick Breyer przeciwko Bundesrepublik Deutschland. URL: https://eur-lex.europa.eu/legal-content/PL/TXT/HTML/?uri=CELEX:62014CJ0582\&from=SV.

${ }^{17}$ Wyrok Naczelnego Sądu Administracyjnego w sprawie I OSK 1079/10 dnia 19.05.2011. URL: http://orzeczenia.nsa.gov.pl/doc/42DC7AE3F0.
} 
Аналіз вітчизняного законодавства дозволяє стверджувати, що не існує чітких обмежень у використанні персональних даних одержувачів цифрового контенту його постачальниками. На перший погляд, необхідність отримання згоди суб'єкта персональних даних, яка є передумовою їх використання, повинна виступати ключовим фактором формулювання права особи самостійно приймати рішення про збір, накопичення, обробку, зберігання та поширення іiї персональних даних, у т. ч. з метою отримання прибутку.

Проте у законодавстві України надання згоди на обробку та використання персональних даних у цифровій сфері визначається як проставлення відмітки про надання дозволу на обробку своїх персональних даних під час реєстрації в інформаційно-телекомунікаційній системі суб'єкта електронної комерції ${ }^{18}$. Вважаємо, такий підхід до захисту персональних даних від їх подальшого використання постачальником у рекламних і маркетингових цілях неефективним, оскільки для отримання визначеного цифрового блага проставлення зазначеної відмітки $\epsilon$ необхідним. Саме тому для ефективного регулювання відносин у сфері використання персональних даних особи в мережі Інтернет вітчизняне законодавство потребує новелізації. На нашу думку, необхідним є внесення змін до ч. 3 ст. 2 Закону України «Про захист персональних даних» та iï викладення у такій редакції: «Згода суб'єкта персональних даних добровільне волевиявлення особи (за умови їі поінформованості) щодо надання дозволу на обробку іiі персональних даних відповідно до сформульованої мети обробки, висловлене у письмовій формі або у формі, що дає змогу зробити висновок про надання згоди. У сфері електронної комерції, постачання цифрового контенту та цифрових послуг згода суб'єкта персональних даних може надаватися під час реєстрації в інформаційно-телекомунікаційній системі суб'єкта електронної комерції, постачальника цифрового контенту шляхом проставлення відмітки про надання дозволу на обробку персональних даних відповідно до сформульованої мети їх обробки, за умови, що така система не створює можливостей для обробки персональних даних до моменту проставлення відмітки. Поле проставлення відміток формується у вигляді чекбоксів, які надають користувачу право вибору способу обробки його персональних даних». До вказаних чекбоксів відносимо: 1) надання явної згоди суб'єкта персональних даних на їх обробку та використання виключно з метою виконання постачальником своїх зобов'язань; 2) надання явної згоди суб'єкта персональних даних на їх обробку та використання постачальником у будьякий інший спосіб, у т. ч. для підбору контекстної реклами. Використання

\footnotetext{
18 Про захист персональних даних : Закон України від 01 червня 2010 р. № 2297-VI. Відомості Верховної Ради України. № 34. Ст. 481.
} 
персональних даних повинно обмежуватися тривалістю дії укладеного договору постачання цифрового контенту, а їх суб'єкту має гарантуватися можливість відкликання такої згоди у будь-який момент.

\section{3. Надання персональних даних як еквівалент виконання грошового зобов'язання}

На наш погляд, аналізу потребує питання можливості в межах вітчизняного законодавства визнання персональних даних об'єктом договірних зобов'язань, в т. ч. у сфері обігу цифрового контенту, визначення способу використання персональних даних як оплати ціни у договорі та кваліфікації дій одержувачів цифрового контенту стосовно надання персональних даних як виконання зустрічного зобов'язання у відплатних договорах постачання цифрового контенту.

У світлі цих питань доцільно зауважити, що правовий режим персональних даних, враховуючи їх правову природу, $є$ доволі дискусійним. Це зумовлено, по-перше, тим, що вітчизняний законодавець не відносить персональні дані до об'єктів цивільних прав, проте включення до такого переліку інформації дозволяє шляхом застосування юридичної фікції припустити належність інформації про особу, що по суті і $є$ iii персональними даними, до вказаної категорії. По-друге, у ст. 201 ЦК України законодавець відносить до нематеріальних благ і ім'я особи. Це ставить під сумнів здатність монетизації інформації про ідентифікацію особи, котра включає також іiі ім'я. Основною проблемою у визначенні монетизації персональних даних $\mathrm{i}$, як наслідок, їх надання постачальнику цифрового контенту для використання у комерційних цілях є відсутність у одержувачів цифрового контенту альтернативи у виборі постачальника. Зокрема, пересічний користувач платформи Google, Facebook, Instagram, у зв'язку із неможливістю їх використання без згоди на обробку персональних даних, не пов'язаних із наданням цифрового контенту при реєстрації, по суті добровільно надає таку згоду і тим самим виключає відповідальність постачальника за комерційне використання персональних даних ${ }^{19}$.

Варто відзначити, що наведені платформи використовують технології відстеження поведінки користувачів у мережі Інтернет з метою створення їх комерційних профілів і підбору для таких користувачів спеціальної індивідуалізованої реклами. Наприклад, особі, яка часто відвідує вебсторінки із трансляціями й оглядами спортивних футбольних матчів, при купівлі на сторінці авіакомпанії онлайн квитків до Лондона контекстна реклама запропонує придбати додатково квитки на футбольний матч

\footnotetext{
${ }^{19}$ Gołaczyński J. Wybrane dobre praktyki w zakresie usług elektronicznych. C.H. Bech, 2016. $530 \mathrm{~s}$.
} 
за участі Лондонського клубу «Арсенал», тоді як особі, котра купує на тому самому веб-сайті квитки до Лондона, проте цікавиться модою та стилем, контекстна реклама пропонуватиме відвідати події у сфері моди наприклад, показ британського дизайнера, презентацію косметичного бренду та ін. Варто зауважити, що користувачі Інтернет-платформ здебільшого не здогадуються, наскільки ретельно система збирає, здійснює обробку та продаж їніх персональних даних, наскільки детально можуть відстежуватися дії особи. Сюди належить запам'ятовування пошукових комбінацій у Google, збереження кеш-інформації про відвідані веб-сторінки, в т. ч. збір інформації з мікрофонів і камер мобільного пристрою. Принагідно відзначимо, що у 2007 р. компанія Google уклала договір вартістю 3,1 млн дол. США із компанією Double Click - лідером у галузі надання контекстної реклами більше п'ятнадцяти років. Ця компаніє виступає посередником між власниками веб-сайтів і рекламодавцями, а також розміщує рекламу на веб-сайтах. Для відстеження поведінки осіб у мережі Інтернет використовуються файли кукі (cookie), які розміщуються на веб-сторінках та запам'ятовують і накопичують інформацію про пристрій і персоніфікованих на ньому користувачів з метою їх розпізнання під час повторного відвідання Інтернет-сторінки. Використовуючи ці файли, Double Click має можливість відстежувати поведінку користувачів в Інтернеті, підбирати відповідну контекстну рекламу ${ }^{20}$.

Цікавим для аналізу видається і питання можливості та правових наслідків відкликання згоди користувача на обробку та використання його персональних даних. Досліджуючи положення ст. 8 Закону України «Про захист персональних даних», ми бачимо, що законодавець надає суб'єкту персональних даних право відкликати згоду на їх обробку, проте не встановлює способу та правових наслідків його реалізації.

Єдиним документом, який містить роз'яснення у сфері відкликання згоди на обробку персональних даних, є Лист Міністерства юстиції України від 26 квітня 2013 р. № 5543-0-33-13/6.1 «Щодо відкликання згоди на обробку персональних даних», у якому зазначається, що надання згоди на обробку персональних даних за своєю правовою природою є правочином у сенсі ст. 202 ЦК України. Таким чином, відмова від правочину повинна бути здійснена у тій самій формі, в якій було його вчинено ${ }^{21}$. Наведене положення фактично підтверджує можливість персональних даних виступати об’єктом правочину та мати визначену ціну.

\footnotetext{
${ }^{20}$ Sloot B., Borgesius F. Google and Personal Data Protection. URL: https://www.academia.edu/9625192/ Chapter_4_Google_and_Personal_Data_Protection?email_work_card=view-paper.

21 Щодо відкликання згоди на обробку персональних даних : Лист Міністерства юстиції України від 26 квітня 2013 р. № 5543-0-33-13/6.1 URL: https://zakon.rada.gov.ua/laws/show/v5543323-13\#Text.
} 
У літературі виділяють три основні моделі надання монетизованих персональних даних за договорами постачання цифрового контенту. До першої 3 них належить укладення договорів, на підставі яких постачальник надає або зобов'язується надати одержувачу товар або послугу (в т. ч. цифровий контент), а одержувач зобов'язується сплатити певну суму грошових коштів і надати постачальнику для використання свої персональні дані. Другою $є$ укладення договору, за умовами якого постачальник надає або зобов'язується надати одержувачу товар або послугу (в т. ч. цифровий контент) квазібезвідплатно, а одержувач зобов'язується надати постачальнику свої персональні дані (в т. ч. адресу електронної пошти, інформацію про хостинг файлів, редагування файлів та ін.). Отримуючи персональні дані, постачальник цифрового контенту створює електронні профілі користувачів із інформацією про їхню стать, вік, місце знаходження, адресу електронної пошти, вподобання (за результатами аналізу відвідуваних Інтернет-ресурсів) та ін. ${ }^{22}$. Такі інформаційні профілі у разі існування згоди на обробку персональних даних осіб, у них вміщених, відповідно до національного законодавства можуть бути предметом договорів. Таким чином, отримуючи персональні дані, постачальник цифрового контенту отримує прибуток шляхом їх подальшого збуту рекламним компаніям, а одержувач цифрового контенту отримує непотрібну та часом надокучливу, персоніфіковану контекстну рекламу. Тому договори, за умовами яких одержувач цифрового контенту надає свої персональні дані та дозвіл на їх використання, не можуть вважатися безвідплатними, оскільки дані, що надаються, $є$ предметом подальшого цивільного обороту та мають визначену ціну.

Третьою виступає модель постачання цифрового контенту за договором, на підставі якого одержувачу надається доступ до нього на визначений період у часі безвідплатно, з умовою передання персональних даних, а після завершення так званого тестового режиму використання цифрового контенту договір може бути продовженим на підставі здійснення одержувачем додаткової оплати ціни (у формі грошових коштів) договору. Рисою, що об'єднує наведені договірні моделі є обов'язкове надання одержувачем

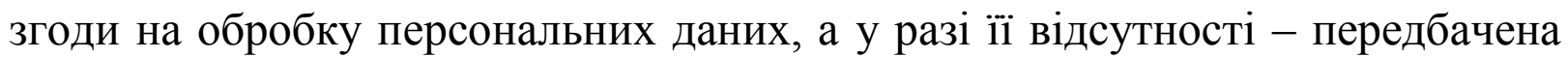
оплата еквівалентної суми грошових коштів. Таким чином, у кожному конкретному випадку, враховуючи ціну договору, можемо визначити вартість наданих за умовами такого договору персональних даних, що відповідно до норм цивільного законодавства встановлюється у розмірі, еквівалентному ціні, яка склалася на аналогічні товари, або послуги.

\footnotetext{
${ }^{22}$ Gołba L. Personal data trading under polish contract law. Osteuroparecht. Vol. 2. 2017. P. 186-205.
} 
Окрім того, варто відзначити, що надання персональних даних як оплати договору постачання цифрового контенту не означає, що їх слід кваліфікувати еквівалентом грошових коштів, в т. ч. електронних. Відповідно до ст. 15 Закону України «Про платіжні системи та переказ коштів в Україні» від 05 квітня 2001 р. № 2346-III ${ }^{23}$ під електронними грошима розуміються одиниці вартості, які зберігаються на електронному пристрої, приймаються як засіб платежу іншими особами, ніж особа, котра їх випускає, і є грошовим зобов'язанням цієї особи, що виконується в готівковій або безготівковій формі. Варто відзначити, що випуск таких грошей може здійснювати виключно банк шляхом їх надання користувачам або комерційним агентам в обмін на готівкові або безготівкові кошти.

Цікавим видається німецький підхід до використання персональних даних як способу оплати у договірних зобов'язаннях і встановлення для них режиму розрахункової одиниці (rechnungseinheit), що має визначену грошову вартість і може застосовуватися для договірних розрахунків ${ }^{24}$. До таких розрахункових одиниць, що не є грошовими коштами, відносять $\mathrm{i}$ криптовалюту у формі біткойнів, щодо якої нині також відсутня однозначна позиція Національного банку України ${ }^{25}$.

Досліджуючи питання необхідності впровадження у національне законодавство відповідних норм, які дозволятимуть інтерпретувати надання персональних даних як форму виконання грошового зобов'язання, варто відзначити, що такий механізм передання персональних даних є фактично діючою конструкцією відплатного договору на цифровому ринку України.

\section{ВИСНОВКИ}

Таким чином, доходимо висновку про доцільність доповнення законодавства України у сфері захисту персональних даних положеннями про їх монетизацію. Зокрема, вважаємо необхідним внесення змін до ст. 8 Закону України «Про захист персональних даних», що визначає права суб'єкта персональних даних, шляхом іiї доповнення п. 14 ч. 2 такого змісту: «На монетизацію персональних даних у разі укладення договорів, за якими здійснюється постачання цифрового контенту».

Отже, персональні дані як інформація, що дозволяє ідентифікувати особу, $\epsilon$ об'єктом цивільних прав і має визначену майнову вартість. 3 метою ефективного регулювання правовідносин, за якими надаються персональні

\footnotetext{
${ }^{23}$ Про платіжні системи та переказ коштів в Україні : Закон України від 05 квітня 2001 р. № 2346-III. Відомості Верховної Ради Украӥни. 2001. № 29. Ст. 137.

${ }^{24}$ Gesetz über das Kreditwesen (Kreditwesengesetz - KWG). URL: https://www.gesetze-im-internet.de/kredwg/ KWG.pdf.

${ }^{25}$ Kilian W. Non-monetary counter performance in online-contracts relating to digital content. Ius est ars boni et aequi. Księga pamiątkowa dedykowana profesorowi Józefowi Frąckowiakowi. Wroclaw, 2018. $1380 \mathrm{~s}$.
} 
дані, доцільним є застосування юридичної фікції та поширення на них правового режиму майна. Договір, за яким постачання цифрового контенту здійснюється в обмін надання його одержувачем персональних даних, є відплатним, за винятком, коли їх передання необхідне виключно для здійснення постачання цифрового контенту, без наміру їх подальшого використання для досягнення будь-яких інших цілей.

\section{АНОТАЦІЯ}

У статті здійснюється теоретичне дослідження проблематики надання персональних та інших даних як способу відплатності у договорах постачання цифрового контенту. Проведено порівняльний аналіз ступеня ефективності національного законодавства у сфері захисту персональних даних із законодавством ЄС. Розглянуто можливість і правові наслідки віднесення персональних даних до переліку об'єктів цивільних прав. Проаналізовано підхід Суду Справедливості ЄС до доцільності розширення переліку інформації, яка може бути кваліфікована як персональні дані. Досліджено доцільність включення до переліку персональних даних інформації про IP-адресу одержувача цифрового контенту. Авторами обгрунтовано необхідність внесення змін у чинне законодавство України, що регулює використання персональних даних. Доведено доцільність кваліфікації договору, за яким здійснюється постачання цифрового контенту в обмін на надання персональних даних, як відплатного.

\section{ЛITEPATУРA}

1. Proposal for a Directive of the European Parliament and of the Council on certain aspects concerning contracts for the supply of digital content COM/2015/0634 final - 2015/0287 (COD). URL: https://eur-lex.europa.eu/legalcontent/EN/TXT/?uri=celex\%3A52015PC0634 (дата звернення 27.11.2020).

2. Directive (EU) 2019/770 of the European Parliament and theof the Councilof 20 May 2019 on certain aspects concerning contracts for the supply of digital content and digital services. URL: https://eur-lex.europa.eu/legal-content/EN/ $\mathrm{TXT} / \mathrm{PDF} /$ ?uri=CELEX:32019L0770\&from=EN (дата звернення 27.11.2020).

3. Klein A. Elementy zobowiązaniowego stosunku prawnego. Wrocław : Wydawnictwo Uniwersytetu Wrocławskiego. 2005. $200 \mathrm{~s}$.

4. Nowacka I. Umowa o dostarczeniu tresci cyfrowych. Kraków, 2017. 420 s.

5. Pormeister K. Informed consent to sensitive personal data processing for the performance of digital consumer contracts on the example of ' 23 andMe'. Journal of European Consumer and Market Law. 2017. № 1. P. 17-24.

6. Прапорець (елемент GUI). URL: https://uk.wikipedia.org/wiki/\%D0\%9F\% D1\%80\%D0\%B0\%D0\%BF\%D0\%BE\%D1\%80\%D0\%B5\%D1\%86\%D1\%8C_ 
(\%D0\%B5\%D0\%BB\%D0\%B5\%D0\%BC\%D0\%B5\%D0\%BD\%D1\%82_GUI) (дата звернення 27.11.2020).

7. Helberger N., Loos M., Guibault L., Mak C., Pessers L. Digital content contracts for consumers. Journal of Consumer Policy. 2013. Vol. 36. Issue 1. P. 37-57.

8. Directive of the European Parliament and the Council on the protection of individuals with regard to the processing of personal data and on the free movement of such data 95/46/EC dated 24.10.1995. URL: http://eur-lex.europa.eu/legal-content/EN/TXT/?uri=CELEX\%3A31995L0046 (дата звернення 27.11.2020).

9. Directive of the European Parliament and the Council concerning the processing of personal data and the protection of privacy in the electronic communications sector (Directive on privacy and electronic communications) 2002/58/EC dated 12.07.2002. URL: http://eur-lex.europa.eu/legal-content/EN/ $\mathrm{TXT} /$ ?uri=celex\%3A32002L0058.

10. Handbook on European data protection law. URL: http://www.echr.coe.int/ Documents/Handbook_data_protection_ENG.pdf (дата звернення 27.11.2020).

11. Metzger A. Data as Counter-Performance: What Rights and Duties do Parties Have? URL: https://www.jipitec.eu/issues/jipitec-8-1-2017/4528.

12. Purtova N. Property rights in personal data: A European perspective. URL: https://pure.uvt.nl/ws/files/1312691/Purtova_property16-02-2011.pdf (дата звернення 27.11.2020).

13. Mańko R. Contracts for supply of digital content. A legal analysis of the Commission's proposal for a new directive. URL: http://www.europarl. europa.eu/RegData/etudes/IDAN/2016/582048/EPRS_IDA(2016)582048_EN.pdf (дата звернення 27.11.2020).

14. Wyrok Trybunału w sprawie C-582/14 Patrick Breyer przeciwko Bundesrepublik Deutschland. URL: https://eur-lex.europa.eu/legal-content/ $\mathrm{PL} / \mathrm{TXT} / \mathrm{HTML} /$ ?uri=CELEX:62014CJ0582\&from=SV (дата звернення 27.11.2020).

15. Wyrok Naczelnego Sądu Administracyjnego w sprawie I OSK 1079/10 dnia 19.05.2011. URL: http://orzeczenia.nsa.gov.pl/doc/42DC7AE3F0 (дата звернення 27.11.2020).

16. Конвенція про захист осіб у зв'язку з автоматизованою обробкою персональних даних. URL: https://zakon.rada.gov.ua/laws/show/994_326 (дата звернення 27.11.2020).

17. Про захист персональних даних : Закон України від 01 червня 2010 p. № 2297-VI. Відомості Верховної Ради України. № 34. Ст. 481.

18. Gołaczyński J. Wybrane dobre praktyki w zakresie usług elektronicznych. C.H. Bech. 2016. $530 \mathrm{~s}$. 
19. Sloot B., Borgesius F. Google and Personal Data Protection. URL : https://www.academia.edu/9625192/Chapter_4_Google_and_Personal_Data_ Protection?email_work_card=view-paper (дата звернення 27.11.2020).

20. Щодо відкликання згоди на обробку персональних даних : Лист Міністерства юстиції України від 26 квітня 2013 р. № 5543-0-33-13/6.1 URL: https://zakon.rada.gov.ua/laws/show/v5543323-13\#Text (дата звернення 27.11.2020).

21. Gołba L. Personal data trading under polish contract law. Osteuroparecht. Vol. 2. 2017. P. 186-205.

22. Про платіжні системи та переказ коштів в Україні : Закон України від 05 квітня 2001 р. № 2346-III. Відомості Верховної Ради Украйни. 2001. № 29. Ст. 137.

23. Gesetz über das Kreditwesen (Kreditwesengesetz - KWG). URL: https://www.gesetze-im-internet.de/kredwg/KWG.pdf (дата звернення 27.11.2020).

24. Kilian W. Non-monetary counter performance in online-contracts relating to digital content. Ius est ars boni et aequi. Księga pamiątkowa dedykowana profesorowi Józefowi Frąckowiakowi. Wroclaw, 2018. 1380 s.

Information about authors: Stakhyra H. M., Senior Lecturer at the Department of International Law and Migration Policy West Ukrainian National University 11, Lvivska str., Ternopil, 46000, Ukraine

Baran A. V.,

Candidate of Law, Associate Professor, Associate Professor at the Department of International Law and Migration Policy

West Ukrainian National University 11, Lvivska str., Ternopil, 46000, Ukraine 